\title{
СОВРЕМЕННЫЕ ТРЕНДЫ И ВЫЗОВЫ ИНДУСТРИИ ПИТАНИЯ
}

\author{
Рождественская Лада Николаевна \\ канд. экон. наук, доцент \\ ФГБОУ ВО «Новосибирский государственный \\ технический университет»
}

\begin{abstract}
Аннотация: Стремительное изменение технологий, цифровизация экономики, необходимость выбора форм потребления и производства, не противоречащих устойчивому развитию, привели к целому ряду социальноэкономических изменений в индустрии питания. В материале рассмотрены научные достижения, изменения в потребительских предпочтениях, технологические и информационные преобразования, определяющие будущее развитие отрасли.
\end{abstract}

Ключевые слова: общественное питание, биотехнологии, фудомика, персонализированное питание, пищевые технологии.

\section{MODERN TRENDS AND CHALLENGES IN THE FOOD INDUSTRY}

\author{
Rozhdestvenskaya Lada Nikolaevna \\ Cand. Sc. (Economics), Ass. Professor \\ Novosibirsk State Technical University
}

\begin{abstract}
The rapid change in technology, the digitalization of the economy, the need to choose forms of consumption and production that do not contradict sustainable development have led to a number of socio-economic changes in the food industry. The material considers scientific achievements, changes in consumer preferences, technological and informational transformations that determine the future development of the industry.
\end{abstract}


Key words: public catering, biotechnology, food industry, personalized nutrition, food technology.

\section{1. Современные тренды и вызовы индустрии питания}

\section{1. Научные предпосылки трансформации в индустрии питания}

После совместного заявления представителей двух исследовательских групп - International Human Genome Sequencing Consortium (IHGSC) и Celera Genomics в 2000 году, о том, что проводимые с 70-х годов прошлого столетия работы по расшифровке генома человека закончены, произошло активное развитие целого спектра новых научных дисциплин - омов и омиков. Они образованы путем использования базового термина «геном», обозначающего совокупность хромосом организма, и прочно заняли свое место в современной биологии - например, геномика, транскриптомика, протеомика и метаболомика.

Фудомика (foodomics), как новое научное направление, не стала исключением, и, появившись в 2009 году [1], стала активно использоваться как для разработки новых пищевых продуктов и изучения важных аспектов науки о пище и питании, так и для обеспечения безопасности и качества пищи, включая мониторинг генномодифицированных продуктов [2].

Foodomics - мощный инструмент для определения компонентов пищи и питательных веществ на молекулярном уровне. В последнее время исследования в области пищевых продуктов были поддержаны использованием аналитических методов в различных омических дисциплинах, таких как протеомика, метаболомика, липидомика, нутригеномика, метагеномика и транскриптомика. Во многих исследовательских работах рассматривается использование различных омикс-технологий по отдельности или в комбинации не только для анализа компонентов пищевых продуктов, но и для аутентификации пищевых продуктов и оценки их безопасности и качества [3]. 


\section{СОЦИАЛЬНО-ЭКОНОМИЧЕСКИЕ ПРОЦЕССЫ: НОВОЕ ВИДЕНИЕ, ВЫЗОВЫ, ТЕНДЕНЦИИ}

Очевидно, что использование передовых аналитических методов в исследованиях омики дало ученым возможность взглянуть на науку о пищевых продуктах и питании с широкой точки зрения [4]. На основе агрегации множества генетических данных стали развиваться методы молекулярно-генетических исследований, что привело к развитию новой научной дисциплины нутригеномики [5]. В свою очередь, определение биохимических путей взаимодействия компонентов пищи и генов позволяет находить новые эффективные методы лечения многих хронических неинфекционных заболеваний таких как: сердечно-сосудистые и метаболические заболевания диабет, ожирение. За счет выявления и дальнейшего контроля ранних маркеров нарушений метаболизма возможно предотвращение их развития на основе составления персонализированных рационов здорового питания [6].

Немаловажное открытие в решении вопросов разработки персонализированного питания играет не только расшифровка генома человека, но и расшифровка микробиома кишечника человека, совокупный микробный геном которого содержит 3,3 миллиона кодирующих сиквенсов (открытых рамок считывания) против 30 тысяч в геноме хозяина. Эти открытия позволяют сформировать устойчивую и научно-обоснованную позицию в основе рекомендаций по питанию, поддерживающего необходимый состав и микробиомные популяции основного микробиома, в том числе превалирующих 4 бактериальных филумов [7].

Технологический радар FoodNet по направлению «Персонализированное и специализированное питание предусматривает решение задачи персонализации рационов питания на основе анализов генома и микробиома уже в среднесрочной перспективе, т.е к 2030-2035 гг. [8].

В зависимости от вариаций в одном гене, дополненных воздействием факторов внешней среды выделяют моно- и полигенные заболевания. В свою очередь вариации в генах определяют предрасположенность к возникновению 


\section{СОЦИАЛЬНО-ЭКОНОМИЧЕСКИЕ ПРОЦЕССЫ: НОВОЕ ВИДЕНИЕ, ВЫЗОВЫ, ТЕНДЕНЦИИ}

заболеваний и отражаются на усвоении и метаболизме пищи. На основе понимания этих процессов, которые изучают нутригенетика и нутригеномика и с учетом особенностей генотипа ранжируются риски употребления тех или иных продуктов и формируются индивидуальные рекомендации по их исключению или, наоборот, системному профилактическому употреблению в рационе питания. Поскольку клеточный фенотип достаточно пластичен и зависит от рациона потребления определенных пищевых продуктов изменением микробиома и физических нагрузок, современной формой терапевтического вмешательства стала персонализированная нутригеномная терапия, основанная в первую очередь на персонализированной нутриентологии.

Совокупность нутригенетики и, так называемых омикс-платформ, являющихся новыми молекулярными технологиями, основанными на использовании биомаркеров - фудомики, нутримиромики, нутригеномики, пептидомики, метаболомики, микробиомики, транскриптомики и системной биологии открыли новые возможности в индустрии питания. В то же время это дало понимания необходимости тщательнейшего контроля качества и безопасности пищевых продуктов, применяемых в питании индивидуума с целью достижения эффектов нутригеномной терапии.

С целю гарантий прослеживаемости, качества и безопасности аналитические методы, основанные на омикс-платформах оказываются незаменимыми. Постоянно развивающаяся на их основе аналитическая методология приводит к появлению все более чувствительных и экономичных, в отличие от традиционных, аналитических методов. Они позволяют идентифицировать введенные, но не указанные в составе продукции производителем пищевые добавки, определить длительность сроков транспортировки на соблюдение в процессе требуемых режимов хранения, выявлять намеренно фальсифицированную продукцию и спрогнозировать возможное влияние на организм. 
Так, появилось множество специфических методик, призванных обеспечить на основе конкретных физико-химических взаимодействий полную информацию о компонентах исследуемых образцов: массспектрометрия, инфракрасная и атомная спектроскопия; спектроскопия в ультрафиолетовом и видимом свете; флуоресцентная спектроскопия, круговая спектроскопия дихроизма и ядерный магнитный резонанс. Разделение различных компонентов сложных по составу пищевых продуктов осуществляется с помощью высокоэффективной и сверхкритической жидкостной хроматографии, газовой и ионообменной хроматографии, электрофореза и др. Для определения воздействия пищевых продуктов на здоровье, активно начали использоваться различные иммунологические методы, такие как: иммуноферментный и иммуно-радиометрический анализы, иммунофлуоресцентный анализ, хемилюминесцентный иммуноанализ, иммунный точечный анализ, радиоиммуноанализ и др.

С другой стороны, использование высокотехнологичных аналитических методов предъявляет и особые требования к пробоподготовке, которые должны при минимальном расходе трудозатрат, лабораторных растворителей, времени и стоимости лабораторных образцов обеспечить максимальную эффективность выделения аналита. Наилучшие возможности в современном мире для этого дает использование при пробоподготовке полимеров с молекулярным отпечатком, а также различные методы экстрагирования от фазовой микроэкстракции и сверхкритической флюидная экстракция до использования экстракции с помощью ультразвука (для оценки загрязнителей в пищевых продуктах).

Таким образом, к основным результатам использования достижений современной науки, предопределяющим дальнейшее развитие индустрии питания, можно отнести:

возможность более точно и быстро определять микробный профиль, состав и проведения технологической обработки, как для различных сложных 
продуктов питания, так и генетически модифицированных культур на основе использования методов, основанных на выделении ДНК и молекулярных методов;

возможность обнаружения пищевых компонентов, консервантов, пищевых красителей и подсластителей, а также загрязнение токсинами, пестицидами, антибиотиками, гормонами, микробами и т. д на основе использования биосенсоров (в т.ч. такие аналитические устройства, как электронные нос и язык);

возможность аутентификации и анализа пищевых продуктов, выявления наличия аллергенов и остатков ветеринарных препаратов в пище путем использования технологий на основе пептидных нуклеиновых кислот;

возможность создания как отдельных видов блюд, так и рационов для персонализированного питания отдельного индивидуума с учетом его индивидуальных генетических особенностей;

возможность разработки новых видов специализированных и функциональных продуктов, поддерживающих необходимый состав и микробиомные популяции основного микробиома - в частности новые «биотики» [9], включая пробиотики, пребиотики, синбиотики, постбиотики, онкобиотики, парапробиотики, фармакобиотики и психобиотики $[10,11]$.

\section{2. Обзор мировых потребительские трендов (Consumer Trends),} определяющих развитие индустрии питания

Развитие индустрии питания предусматривает активную трансформацию на всех уровнях: меняются тренды, популярность концепций и конкретных заведений, потребительские стереотипы, используемые технологии и продукты. Всё это является достаточно плохо прогнозируемой частью бизнеса, поскольку питание - это часть культуры человека, а в условиях имеющихся вызовов и тотальной глобализации происходит значительное ускорение социально - экономических процессов. 
Результаты изучения потребительских трендов 2020 года (Consumer Trends for 2020) [12] охватывающие потребителей из Австралии, Франции, Германии, Малайзии, Мексики, Сингапура, Испании, объединенное Королевства Великобритании и Соединенных Штатов показывают общую озабоченность грядущими за технологическими инновациями изменениями в мире в целом. При этом наибольшее влияние предполагается, будут оказывать «возобновляемая» энергии - «Renewable energy» и 5G - технологии, также отмечаются «роботы», «BlockChain», «криптовалюта» и «Автомобили с автоматическим управлением». Как конкретно эти тренды скажутся на индустрии питания в 2020 сложно предположить, но то что они оказывают влияние и трансформируют бизнес - процессы не вызывает сомнений. Уже сегодня существуют предприятия, отапливаемые путем переработки пищевых отходов, использующие возможности беспилотного транспорта для доставки. Способность технологии «BlockChain», создавать отслеживаемые записи на протяжении жизненного цикла продукта рассматривается как ключ к тому, как операторы питания подходят к обеспечению безопасности и прослеживаемости происхождения используемого сырья и ингредиентов. Приложения для обеспечения отслеживания и сохранности продуктов питания, такие как Goodr [13], лидируют по активности внедрения в отрасли.

В то же время уже сегодня невозможно полноценное функционирование предприятия питания без использования мобильных систем и социальных сетей, а развитие стандарта 5G необходимо для масштабного функционирования «интернета вещей». Благодаря этой технологии к интернету можно будет подключить десятки миллионов устройств - от беспилотных автомобилей до «умных» электрочайников. Пятое поколение открывает возможности для внедрения новых технологий в различные сферы экономики: речь идет о повышении производительности роботов на предприятиях и дистанционном управлении техникой. 


\section{СОЦИАЛЬНО-ЭКОНОМИЧЕСКИЕ ПРОЦЕССЫ: НОВОЕ ВИДЕНИЕ, ВЫЗОВЫ, ТЕНДЕНЦИИ}

Исследования факторов принятия решения о покупке по странам, говорят о значительном перевесе в сторону «опыта семьи, друзей или коллег» - этим руководствуются большинство потребителей в мире - 33\% и только в Малайзии лидерство при принятии решений остается за «он-лайн обзорами» (в мире - 3-е место - 17\%). На втором месте с 19\% - имеющийся прежде опыт потребления. Для индустрии питания эта информация важна с точки зрения расставляемых приоритетов при построении CRM - системы. Особую роль при этом играет то, что поколения $\mathrm{X}, \mathrm{Y}$ и $\mathrm{Z}$, выделенные по схожести ценностей и типу мышления по-разному формируют решение о покупке, что важно при сегментации рынка и диверсификации предлагаемых предприятиями питания услуг и продуктов.

Так, например, на основе изучения мировых трендов и приоритетов потребительского поведения в индустрии питания $[14,15]$ был выделен набор значимых для клиентов ценностей, которые, определят потребительский выбор предприятий фастфуда в 2020 году в разных странах мира. При исследовании глобальных брендов фастфудов было выявлено следующее:

- потребители из Малайзии наиболее высоко оценивают «дружелюбное обслуживание клиентов» и «персонализацию». Также отдельно выделяется возможность индивидуального исполнения заказа под потребности гостя

- В Мексике, Испании и Великобритании особенно сильно демонстрировалось превосходство атрибута «Качество» над «Доступностью» по сравнению с другими странами, в общем, практически все страны указывают, что «Качество» и «Удобство» ценится выше «Доступности»:

- Для австралийских респондентов особенно важно «Удобство» по сравнению с «Доступностью»;

- возрастная группа от 18 до 24 (самая младшая из изучаемых) с большей вероятностью, чем другие возрастные группы, выбирала 
«Доступность» и реже выбирала «Качество».

При анализе факторов, влияющих на выбор потребителями предприятия фастфуда, сложилось следующее распределение: «Качество» отметило 36\% опрошенных, 15 \% выбирают «Удобство» и по 12\% приходится на критерии «Доступности» и «Скорости обслуживания». В совокупности на «Устойчивасть», «Персонализацию» и «Сервисные и продуктовые инновации приходится 9\%.

Среди важнейших атрибутов, которые играют роль при выборе предприятия ресторанной индустрии, $49 \%$ от опрошенных назвали «Качество», «Дружелюбное обслуживание клиентов» указало - 15\%, «Доступность» - 13\%, на «Удобство» обращает внимание 6\% а 5\% на «Скорость обслуживания - 5\%. Каждый из факторов: «Персонализация», «Сервисные и продуктовые инновации» и «Устойчивость» способны повлиять на выбор в $3 \%$ случаев.

В целом иерархию самого высокого и самого низкого атрибута по странам можно отследить на примере данных табл.1.

Таблица 1

Атрибуты ресторанных брендов, имеющих наибольшую и наименышую ценность в 2019-20 году

\begin{tabular}{|l|l|l|}
\hline \multicolumn{1}{|c|}{ Страна } & \multicolumn{1}{|c|}{ Переоценениваются } & \multicolumn{1}{|c|}{ Недооцениваются } \\
\hline Австралия & \multicolumn{1}{|c|}{-} & $\begin{array}{l}\text { «Быстрое обслуживание } \\
\text { клиентов» }\end{array}$ \\
\hline Франция & $\begin{array}{l}\text { Устойчивость», } \\
\text { «Доступность» }\end{array}$ & «Безопасность» \\
\hline Германия & $\begin{array}{l}\text { «Дружественное } \\
\text { обслуживание клиентов» }\end{array}$ & «Удобство» \\
\hline Малайзия & $\begin{array}{l}\text { «Быстрое обслуживание } \\
\text { клиентов», «Дружелюбное } \\
\text { обслуживание клиентов» }\end{array}$ & \\
\hline
\end{tabular}


Продолжение таблицы 1

\begin{tabular}{|l|l|l|}
\hline Мексика & $\begin{array}{l}\text { «Еезопасность», «Удобство» } \\
\text { Сингапур }\end{array}$ & $\begin{array}{l}\text { «Доступность, } \\
\text { экономичность» }\end{array}$ \\
\hline Испания & - & «Качество» \\
\hline Великобритания & - & $\begin{array}{l}\text { «Дружелюбное } \\
\text { обслуживание клиентов» }\end{array}$ \\
\hline США & - & - \\
\hline
\end{tabular}

Обобщая вышесказанное необходимо отметить, что чем больше изучаются различия между миллениалами (людьми, родившимися с середины 80-х до 1996 года) и предыдущими поколениями, тем яснее становится важность стимулировании перемен в сфере общественного питания. По сравнению с потребителями поколения Х, родившимися между 1965 и 1985 годами, Millennials pеже ходят в рестораны, поскольку отдают предпочтение доставке и автоматизации заказов и оплаты. 52\% millennials указывают, что они пообедают в ресторане, где заказы и платежи полностью автоматизированы, по сравнению только с 39\% посетителей Gen X. Более двух третей миллениалов (71\%) говорят, что они не будут против того, чтобы их еду доставлял робот. Millennials все больше ориентируют службы общественного питания на устойчивые пищевые альтернативы на основе растений, они видят будущее, где использование экологического растительного сырья превзойдет традиционные нездоровые блюда фастфуда. 49\% опрошенных миллениалов предсказывают, что в ближайшие два года веганские рестораны будут наиболее востребованы, а 75\% думают, что, по крайней мере, один из следующих типов ресторанов будет наиболее востребован: веганский, вегетарианский или ориентированный на экологически чистое сырьё. При этом почти половина $(47 \%)$ всех респондентов считают сокращение пищевых 


\section{СОЦИАЛЬНО-ЭКОНОМИЧЕСКИЕ ПРОЦЕССЫ: НОВОЕ ВИДЕНИЕ, ВЫЗОВЫ, ТЕНДЕНЦИИ}

отходов своим главным устойчивым приоритетом [16]. В то же время $30 \%$ посетителей Millennial говорят, что не пойдут в ресторан со слабым присутствием в Instagram [17]. Все эти тенденции нового поколения потребителей говорят о том, что подходы к разработке меню создаваемых предприятий питания должны быть серьезно пересмотрены, поскольку то, что удовлетворяло потребности более старших поколений теперь не является конкурентоспособным.

Кроме того, необходимо четко понимать, что мир после COVID-19 претерпел существенные изменения и в потребительском поведении, в том числе, успели сформироваться новые привычки и значимые аргументы при принятии решений о покупках. 2020-21 годы были не похож ни на один другой год для индустрии общественного питания, и они проверили пределы инноваций операторов, ускорили тенденции и подтвердили, что клиенты скучают по имеющемуся жизненному опыту посещения ресторанов. Это объясняет появление в индустрии питания в 2020- 2022 гг. новых подходов взаимодействия с потребителями, новых продуктов и технологий, появление новых рыночных ниш, в которых демонстрируется пока невысокая конкуренция, сочетающаяся с высокой WTP (Willlingness to pay) потребительской готовностью платить $[18,19]$.

Не смотря на то, что 2022 год мировая отрасль встречает со снижением объемов продаж, измеряемых десятками миллиардов долларов, и десятками миллионов сотрудников, которые покинули отрасль или по-прежнему не имеют работы в ней, некоторые сформированные в индустрии питания тенденции в отношении отдельных блюд и меню в целом немного компенсировали опустошение.

Так на основе опросов, проведенных Национальной Ассоциацией рестораторов США, охвативших 6000 операторов и 1000 взрослых, в отношении их потребительских предпочтений были выделены основные 


\section{СОЦИАЛЬНО-ЭКОНОМИЧЕСКИЕ ПРОЦЕССЫ: НОВОЕ ВИДЕНИЕ, ВЫЗОВЫ, ТЕНДЕНЦИИ}

операционные инструменты, благодаря которым рестораны выжили в 20202021 годах:

1. Упрощенное и урезанное меню. Поскольку рестораны были вынуждены быстро сокращать запасы и разрабатывать блюда, которые могли бы производиться меньшим штатом сотрудников, быть транспортабельны и желанны потребителями, то произошло значительное сокращение предложения полносервисных ресторанов. Ожидается, что меню в них останется урезанным и в ближайшие месяцы.

2. Выездные заведения получили приоритет. До пандемии $80 \%$ посетителей ресторанов с полным спектром услуг приходилось на локальные. Затем, в марте 2020 года, большинство ресторанов были вынуждены закрыть двери своих заведений. Вероятно, это был самый быстрый разворот в истории отрасли, когда внимание быстро сместилось на вынос и доставку.

3. Смешанные блюда. Находясь дома, клиенты любят смешивать блюда из разных кухонь или направлений, также возможно, они приготовят основное блюдо, но закажут закуски, гарниры или десерт из ресторана. Особенно большие поклонники смешанной еды - миллениалы.

4. Комплексное питание. На итоговый выбор ресторана клиентами теперь может повлиять предложение комплексного питания, которое, может быть реализовано либо простым индивидуальным комплексом (включает закуску, основное блюдо и десерт) либо предложением блюд в семейных упаковках.

5. Наборы для еды. Более половины опрошенных взрослых сказали, что они, скорее всего, купили бы набор для еды, если бы его предложил один из их любимых ресторанов, поскольку это один из вариантов превращения приготовления пищи в удовольствие. Этот процент возрастает до 75\% как для миллениалов, так и для взрослых поколения Z. Наборы содержат предварительно отмеренные ингредиенты и инструкции по приготовлению ресторанной еды дома. 
6. Подписки на питание. Клиенты оформляют подписку на питание в течение месяца для самовывоза или доставки по сниженной цене. Более половины опрошенных потребителей заявили, что подписались бы, если бы их любимые места предлагали такую возможность.

7. Продажа продуктов. Более половины опрошенных потребителей купили бы продукты (свежие, сырые продукты, такие как мясо, продукты, молочные продукты, хлеб или макароны), если бы рестораны предлагали их.

8. Алкоголь на вынос. Треть клиентов (в возрасте 21+) говорят, что они включали алкогольный напиток в заказ на вынос или доставку с начала вспышки COVID-19 и будут продолжать делать это в будущем.

9. «Удобные» продукты. Потребители говорят, что меню, предлагающее хороший выбор удобных с точки зрения потребления и порционирования блюд, влияет на их выбор ресторана. Треть опрошенных ресторанов изысканной кухни добавляют в свой рацион больше продуктов для комфорта — например, гамбургеры, пироги, лазанью, супы, карри, сэндвичи, пиццу и блюда из лапши.

10. Здоровая и диетическая пища. Соответствие принципам здорового питания меню, в той же степени влияет на выбор ресторана, как и «удобство» блюд. В то же время, отмечается, что продукты, специфичные для диеты (безглютеновые, веганские и т. д.) сейчас менее важны.

Указанные изменения демонстрируют гибкость, новаторство и приверженность рестораторов. 72\% посетителей ставят качество еды выше всего остального при выборе ресторан, но еще одним трендом современности стало то, что люди теперь хотят тратить свои деньги на события, которые хорошо смотрятся на камеру и создают интересные посты в социальных сетях. Большую часть маркетинга в социальных сетях теперь делают сами клиенты, а старые формы СМИ исчезают. Практически никто больше не слушает радио, не смотрит телевизор и не читает газеты. И если ресторан хочет привлечь внимание своей аудитории, то с ней придется связаться в цифровом формате и 
платформы социальных сетей стали наиболее эффективным способом сделать это.

Так, один из лучших способов привлечения потребителей сделать ресторан вирусным на TikTok - создать ситуацию, когда влиятельный человек расскажет о нем. Инфлюенсерам доверяют в онлайн-пространстве, и, сотрудничая с ними, можно привлечь аудиторию, которая будет доверять ресторану, потому что они доверяют инфлюенсерам, которых любят и за которыми следят. Так, 84\% людей доверяют онлайн-обзорам так же, как своим друзьям.

Последствием COVID - 19 стало не только более бережное отношение к своему здоровью и востребованность здоровой пищи, но и активный потребительский тренд к устойчивому потреблению. То есть такому потреблению, которое наносит минимальный вред планете и будущим поколениям.

Для оценки отношение потребителей к устойчивым продуктам питания Европейская организация потребителей совместно с 12 организациямичленами из 11 стран ЕС (по 1000 респондентов из каждой страны) провела свое исследование [20]. Оно показало, что потребители, как правило, недооценивают влияние своих пищевых привычек на окружающую среду, хотя и осознают влияние пищевых привычек в целом. Более половины потребителей говорят, что опасения по поводу устойчивости оказывают некоторое $(42,6 \%)$ или большое $(16,6 \%)$ влияние на их пищевые привычки. Две трети потребителей готовы изменить свои привычки в еде по экологическим причинам, при этом многие готовы меньше выбрасывать продукты при домашнем потреблении, покупать больше сезонных фруктов и овощей и есть больше растительной пищи. Тем не менее, сокращение потребления молочных продуктов или увеличение расходов на продукты питания, произведенные экологически безопасным способом, представляют собой более сложную задачу. 
Чуть более $40 \%$ потребителей говорят, что они либо перестали есть красное мясо, либо сократили его из-за экологических соображений. Тем не менее, уровень потребления красного мяса в ЕС по-прежнему намного превышает рекомендуемое потребление для оптимального человеческого здоровья и необходимо приложить больше усилий для поощрения изменения поведения. Это особенно касается тех потребителей (более 1 из 3), которые в настоящее время не хотят есть меньше красного мяса.

В целом, когда речь идет о продуктах питания, потребители в первую очередь видят «устойчивый» как синоним экологически чистого, без ГМО и пестицидов, местного, с некоторыми особенностями в разных странах. В то же время цена, отсутствие информации и проблема определения вариантов экологически чистых продуктов питания, a также их ограниченная доступность являются основными воспринимаемыми препятствиями на пути к устойчивому питанию. Однако идея облагать налогом менее экологически чистые продукты питания не очень популярна среди потребителей (только каждый четвертый согласен с тем, что менее экологически чистые продукты питания должны облагаться более высокими налогами). Более трети потребителей $(38,9 \%)$ поддержали бы правила, обязывающие фермеров и производителей продуктов питания соблюдать более строгие стандарты устойчивого развития. Еще больше (53\%) согласны с тем, что фермерам следует предоставить стимулы (например, посредством субсидий) для более устойчивого производства продуктов питания.

Хотя большинству опрошенных насекомые и культивируемое мясо представляется неаппетитным, потребители с большей вероятностью будут рассматривать «бургеры» на растительной основе (если они приготовлены без ГМО) и традиционные вегетарианские продукты (например, бобовые) в качестве альтернативных источников белка.

Большинство потребителей $(57 \%)$ хотят, чтобы информация об устойчивом развитии была обязательной на этикетках продуктов питания. 


\section{СОЦИАЛЬНО-ЭКОНОМИЧЕСКИЕ ПРОЦЕССЫ: НОВОЕ ВИДЕНИЕ, ВЫЗОВЫ, ТЕНДЕНЦИИ}

Наконец, потребители ожидают, что их правительства возьмут на себя ведущую роль в содействии устойчивому производству и потреблению продуктов питания. Они также хотят, чтобы ЕС придерживался своего нынешнего уровня амбиций в области продовольственной устойчивости, независимо от того, делают ли то же самое другие страны мира. Две трети потребителей готовы изменить свои привычки в еде по экологическим причинам, при этом многие готовы меньше выбрасывать продукты в домашнем быту, покупать больше сезонных фруктов и овощей и есть больше растительной пищи.

Еще одним источником информации о современных потребительских трендах в индустрии питания является аналитика подразделения Human Nutrition химического концерна со 150-летней историей BASF, которое занимается созданием пищевых ингредиентов и красителей. Эксперты концерна выделяют семь основных мировых трендов, которые уже влияют на индустрию питания:

- социально-экологическая устойчивость,

- стареющее население,

- растущая урбанизация,

- рост среднего класса,

- продовольственная безопасность,

- безопасность продуктов питания,

- здоровье и оздоровление [21].

Международный институт маркетинговых исследований MINTEL опубликовал исследование Mintel Announces Global Food and Drinks Trends for 2021 [22]. В нем отмечается, что постпандемия, открывает перед изготовителями продуктов питания и напитков новые возможности - они тесно связаны с тремя движущими силами тенденций: благополучное самочувствие, ценности и самобытность ориентированные на «сейчас» 


\section{СОЦИАЛЬНО-ЭКОНОМИЧЕСКИЕ ПРОЦЕССЫ: НОВОЕ ВИДЕНИЕ, ВЫЗОВЫ, ТЕНДЕНЦИИ}

(следующие 12 месяцев) и «будущее» (пять + лет) потребительского поведения:

Feed The Mind - «Накорми разум»: Инновационные рецептуры продуктов питания и напитков предложат решения для психического и эмоционального благополучия, которые создадут новую основу для здорового питания.

Quality Redefined - «Новое определение качества»: бренды будут вынуждены реагировать на новые определения доверия, качества и «необходимости».

United By Food - «Объединенные едой»: бренды продуктов питания и напитков могут уравновесить потребность человека чувствовать себя уникальным и особенным с желанием быть частью сообщества единомышленников.

В завершении обзора мировых потребительских трендов, которые предопределяют развитие индустрии питания на ближайшие 5 лет можно отметить, что большинство потребителей, особенно в развитых рынках, прекрасно осведомлены о существующих проблемах экологии, что наряду с глобальной цифровизацией всех бизнес - процессов порождает спрос на блюда приготовленные с использованием натуральных продуктов и абсолютной прослеживаемостью. Сегодняшним и завтрашним потребителям нужны продукты, как гарантирующие здоровье и здоровый образ жизни, и учитывающие персональные потребности, так и удобные в использовании. Потребители хотят больше мультисенсорных и функциональных продуктов и напитков, которые повышают способность концентрироваться и расслабляться и уменьшают или, в лучшем случае, предотвращают риски ухудшения эмоционального здоровья. При этом потребители смогут лично проверять эффективность таких блюд и напитков с помощью наручных устройств, отслеживающих физическую активность и состояние. В перспективе можно утверждать, что при увеличении доходов, 
демографических и социальных изменениях спрос на продукты категории «Healh \&Wellness food» намного опередит рынок, а технологические и продуктовые инновации в данной сфере будут высоко востребованными.

\section{3. Технологические тенденции}

На решения, которые будут популярны в дальней и ближней перспективе при разработке предложения в рамках разных концепций особое влияние в ближайшей перспективе окажет целый ряд инноваций индустрии питания. Они появляются, как ответ на вызовы современности и согласно тем ценностям, которые транслируют потребители. Условно все виды новаций, которые необходимо учитывать, можно сгруппировать в сфере следующих групп: оборудование и инвентарь, упаковка и системы инфраструктурного обеспечения.

Среди перспективных видов оборудования стоит отметить возрастающий интерес к использованию полностью автоматизированной техники - роботам, которые находят свое применение в сфере общественного питания в самом разном качестве. Одним из преимуществ использования роботов на производстве в индустрии питания является то, что повторяющиеся задачи или задачи с высокой степенью риска могут быть распределены между механизмами и автоматами, а полученная за счет автоматизации экономия труда может быть передана клиенту в виде более низких цен. Сотрудники ресторанного бизнеса в таком случае имеют больше времени для выполнения творческих задач. Цель роботизации состоит не в том, чтобы заменить людей, а в том, чтобы освободить их для выполнения задач с более высоким уровнем квалификации и более целенаправленной работы с клиентами.

Роботизация имеет мощное распространение и уже сегодня14-футовый прозрачный бот-изготовитель гамбургеров под названием «Творец» «Creator» можно увидеть в ресторане Сан-Франциско. Этот повар — робот, 


\section{СОЦИАЛЬНО-ЭКОНОМИЧЕСКИЕ ПРОЦЕССЫ: НОВОЕ ВИДЕНИЕ, ВЫЗОВЫ, ТЕНДЕНЦИИ}

нарезает булочки, добавляет приправы, жарит мясо и выдает полностью приготовленный гамбургер. Конвейер с булочками движется вправо, опуская одну булочку вниз по желобу, где мини- пила разрезает ее пополам. Машина добавляет топленое масло, поджаривает булочку, и опускает ее в коробку на другую конвейерную ленту, где впрыскивается точное количество каждого соуса по заказу, робот нарезает помидоры и лук в режиме реального времени, натирает сыр и превращает в фарш говядину перед приготовлением каждого бургера. Через пять минут появляется заказанное блюдо, которое стоит около $\$ 6,00[23]$.

В другом кафе Сан- Франциско - Café X с 2017 года работает роботбариста. Есть возможность заказа множество напитков, используя смартфоны или планшеты, также можно выбрать любимое зерно и альтернативу молока, а робот делает все остальное. Стоимость напитка около \$ 3,00 [24]. Гендиректор и основатель Cafe X Генри Ху (Henry Hu) говорит, что идея создания роботизированного кафе у него появилась во время посещения завода Volkswagen в Вольфсбурге (Германия), где он увидел сотни роботов, используемых в производстве автомобилей. «Было бы здорово использовать одного из них для приготовления кофе», - подумал тогда Генри. Генри Ху протестировал технологию Cafe $\mathrm{X}$ в офисе в Гонконге и в офисе одной из компаний Кремниевой долины. Сейчас в научном парке Hong Kong Science Park тоже работает роботизированная мини-кофейня Cafe X.

Первое японское Robot-Café открыло свои двери в 2019 году, когда робот заменил бариста, чтобы подавать кофе посетителям. Клиенты «Henn-na Café» [25], что по-японски означает «Странное кафе», должны отсканировать QR-код, напечатанный на билете, купленном в торговом автомате, чтобы получить кофе за 320 иен (3 доллара США) [26]. Kaфe «Henn Na» расположено в самом сердце туристического агентства HIS в токийском районе Сибуя. Робот - бариста «Том», автономное сочленяющее устройство, которое подает горячий и холодный кофе, чай матча и другие разнообразные 


\section{СОЦИАЛЬНО-ЭКОНОМИЧЕСКИЕ ПРОЦЕССЫ: НОВОЕ ВИДЕНИЕ, ВЫЗОВЫ, ТЕНДЕНЦИИ}

напитки и закуски. Том сродни Cafe $\mathrm{X}$, но не предлагает такого же разнообразия.

Во Франции трехрукий роботизированный пиццайло способен изготавливать 120 пицц в час на заказ с различными ингредиентами, выбор которых осуществляется потребителями с сенсорного экрана. Полностью автоматизированная пиццерия Zume обслуживает потребителей в Калифорнии [27].

Spyce [28] - это стартап в Бостоне со звездными шеф-поварами Даниэлем Булудом, Гэвином Кайсеном и Томасом Келлером. Стоимость порции этнического блюда, приготавливаемого перед клиентами одним из 7 индукционных wok-подобных котлов - 7,5\$. Дополнения можно выбрать на автоматизированной стойке.

Роботизируется не только приготовление пищи, но и обслуживание потребителей. Самым простым вариантом являются роботы - тележки, например, как робот - официант от компании Endurance, который активно используются на различных мероприятиях: конференциях, презентациях в отелях в Москве [29]. Последние новинки китайских роботостроителей появились в Японии. Компания Kunshan Pangolin Robot поставляет человекоподобных роботов для работы в качестве официантов в ресторанах. В апреле компания планирует создать центр исследований и разработок роботов для индустрии питания на базе японского Университета электрокоммуникаций [30].

Новое ресторанное оборудование и тенденции продукта стимулируются требованием большей эффективности и универсальности. Сокращаются производственные помещения, так как растущие арендные платежи способны снизить рентабельность даже успешных концептов. В результате многие владельцы ресторанов выбирают производственное оборудование меньшего размера, которое может выполнять несколько функций для оптимизации своего пространства. Тенденция активного развития фуд - траков, киосков в 


\section{СОЦИАЛЬНО-ЭКОНОМИЧЕСКИЕ ПРОЦЕССЫ: НОВОЕ ВИДЕНИЕ, ВЫЗОВЫ, ТЕНДЕНЦИИ}

фуд-холлах и сезонных ресторанов в местах отдыха породила спрос на оборудование настольного или настенного исполнения, которое способно освободить столь необходимые квадратные метры площади.

Спрос на суперфуды и органическую продукцию привел к тому, что в предприятиях индустрии питания появляются собственные подразделения, которые могут производить свежую, экологически чистую микро-зелень без использования внешнего поставщика. Такую возможность предусматривают шкафы для выращивания зеленых насаждений. Они предназначены для хранения лотков для выращивания с учетом создания условий для регулирования интенсивности освещения или полива, с поддержанием заданной влажности и температуры, позволяющих производить органические травы и даже овощи с улучшенным вкусом. Такие «зеленые кабинеты» (Green Growing Cabinets») устраняют риск потери урожая, давая ресторанным кухням бесконечный запас собственной микро- зелени [31,32].

В связи с растущей популярностью открытых кухонь, особую значимость для оборудования ресторана приобретает презентабельность и зрелищность. Оборудование, которое обычно было вне поля зрения, теперь находится на виду, в центре внимания всех клиентов. Такие конструктивные особенности, как прозрачные окна, обеспечивающие возможность наблюдения за процессом приготовления пищи и предоставляющие гостям захватывающий опыт фуд-шоу, предоставляют новые возможности при разработке ассортимента.

Поскольку все больше рестораторов выбирают нетрадиционные места для своего бизнеса, развиваются технологические решения, позволяющие, приспособить уникальные пространства (холлы торговых центров, офисные помещения и пр.). Системы вытяжек без вентиляции - «Ventless hood systems» [33] позволяют воздуху циркулировать и собирают жир, производимый коммерческим оборудованием для приготовления пищи, без необходимости внешней вентиляции. Это позволяет операторам устанавливать вытяжки в 
местах, которые не поддерживают традиционную систему вентиляции, например в фуд - траках или исторических зданиях, не оснащенных системой воздуховодов.

Тренды устойчивого развития особую роль отводят преимущественному использованию перерабатываемых материалов. Так, производители продолжают находить новые способы, позволяющие избегать использование пластика, в том числе в одноразовой упаковке. Тема одноразового использования пластика в индустрии питания захватывает всех участников логистической цепочки - от поставщиков сырья, до реализаторов готовых блюд и изделий. С помощью новых инновационных продуктов, например, таких как соломинки из сена или полипропиленовые mineral-filled polypropylene containers контейнеры с минеральным наполнением (mineralfilled polypropylene containers) [34] владельцы ресторанов могут значительно ограничить количество используемого пластика и распространить более экологическое видение потребления среди своих потребителей. Так гибридный материал, из которого изготовлены контейнеры с минеральным наполнением, содержит 60\% полипропилена и 40\% натуральных минералов, таких как тальк, что обеспечивает улучшенный экологический оборот. Также полипропилен полностью 100\% может подвергаться вторичной переработке (рециклингу), и является безопасным материалом, поскольку не имеет значительного влияния на здоровье человека и не оказывает на него химическое и токсическое действие.

Всё больше потребителей придерживаются образа жизни «на ходу». Это означает, что они постоянно ищут варианты еды, которые легче брать с собой и употреблять, находясь в движении. Чтобы удовлетворить эту потребность, бренды прилагают дополнительные усилия к тому, чтобы сделать упаковку для пищевых продуктов портативной. Например, McDonald's запустил пакет McBike, ориентированные на велосипедистов. Упаковка позволяет носить с 
собой гамбургер, картофель фри и напитки в складном футляре, который можно закрепить на руле [35].

Для борьбы с изменением климата в индустрии питания всё большее распространение получают более экологичные предприятия. В этих «зелёных» ресторанах и кафе установлены энергосберегающие приборы и солнечные батареи, экономится вода, используются даже биореакторы для переработки отходов, даже их дизайн «работает» на экологию. То есть при строительстве предприятий питания используются необходимые стройматериалы, элементы инфраструктурного обеспечения: подбираются соответствующие природные ландшафты, максимально используется природное освещение и многое другое.

В современном ресторанном бизнесе энергосберегающее оборудование и технологии являются обычным явлением [36,37]: около восьми из десяти операторов ресторанов в мире используют энергосберегающее освещение, а шесть из десяти используют программируемые термостаты отопления, вентиляции и кондиционирования воздуха. Более четырех из десяти используют холодильники, морозильники и ледогенераторы с рейтингом Energy Star [38]. Шесть из 10 ресторанов используют графики запуска/ выключения, чтобы уменьшить потребление энергии производственным оборудованием.

Сокращение пищевых отходов становится ключевым видом деятельности для операторов индустрии питания: около половины рестораторов отслеживают количество пищевых отходов, которые производит их ресторан, и многие операторы (около одного из пяти) жертвуют съедобные остатки пищевых продуктов на благотворительные цели, а каждое из десяти предприятий используют кухонные компостеры для утилизации отходов.

Водосберегающие инновации набирают силу: сантехнические приборы c низким потоком используются примерно в половине ресторанных предприятий. Более одного из четырех ресторанов используют другие 


\section{СОЦИАЛЬНО-ЭКОНОМИЧЕСКИЕ ПРОЦЕССЫ: НОВОЕ ВИДЕНИЕ, ВЫЗОВЫ, ТЕНДЕНЦИИ}

инновации, такие как высокоэффективные клапаны для предварительной промывки и аэраторы для кранов.

Многие операторы делают выбор в пользу упаковки и расходных материалов с меньшим воздействием на окружающую среду. Так 72\% операторов питания в мире покупают упаковку и расходные материалы, содержащие материалы, пригодные для переработки.56\% покупают материалы, сертифицированные как компостируемые [39].

Усилия предприятий индустрии питания по обеспечению устойчивости могут повлиять на выбор ресторана гостей, поскольку около половины потребителей говорят, что усилия ресторана по переработке, сохранению продуктов питания или сокращению пищевых отходов могут быть факторами, по которым они предпочитают обедать именно в нём.

И здесь особенно важно понимать, что в мире, где робототехника, искусственный интеллект и виртуальная реальность становятся будущим индустрии питания; где достижения в IT - сфере и медицине позволяют разрабатывать новое поколение специализированного и персонализированного питания; где в коммерческую кухню проникает и становится все более предсказуемой.3D-печать; [40] ассортимент, предлагаемый предприятиями отрасли становится результатом неразрывного симбиоза техники, науки и творчества.

\section{4. Продуктовые и сервисные тренды (Foodservice trends)}

Появление новых потребительских ожиданий, прорывных технических, технологических и IT - решений, нетрадиционных сырьевых источников и способов их производства, синтез экологически безопасных материалов, всё это приводит к изменению сферы общественного питания, к появлению актуальных концепций и форматов, которые опираются на современные приоритеты и ценности. 


\section{СОЦИАЛЬНО-ЭКОНОМИЧЕСКИЕ ПРОЦЕССЫ: НОВОЕ ВИДЕНИЕ, ВЫЗОВЫ, ТЕНДЕНЦИИ}

При этом важно понимать, что предприятия питания производят, как продукцию в виде блюд, изделий и полуфабрикатов, так и целый комплекс, связанных с организацией их потребления услуг. И с этой точки зрения современный рынок демонстрирует революционные решения, которые, несомненно, влияют на изменение требований к процессу разработки и внедрения меню.

Глобальному рынку доставки продовольствия, оцениваемому на конец 2017 года в более чем 100 миллиардов долларов [41], предрекали удвоение к 2023 году. Процессы, смещения оборотов ресторанного бизнеса в сегмент доставки, связанные с пандемией COVID-19, делают эти прогнозы ещё более реалистичными. Плюс возникает повышенный спрос на концепции, сокращающие физическое контактное взаимодействие между потребителями и производителями, с одной стороны, но позволяющими идентифицировать и адресно предлагать потенциально востребованные продукты и услуги, с другой. Бурное развитие технологий создает стремительную смену актуальных трендов, и современный ландшафт гостеприимства в ресторанном бизнесе может неузнаваемо измениться за ближайшие 5-7 лет.

Так, например, развитие искусственного интеллекта окажет глубокое воздействие, как на протекание производственных, так и сервисных процессов. Способность искусственного интеллекта агрегировать и глубоко анализировать данные позволит глубоко персонализировать взаимоотношения с клиентами, легко приспосабливая предложения к индивидуальным пищевым предпочтениям, предпочитаемому способу оплаты, диетологическим рекомендациям и диетическим ограничениям, выбираемому стилю обслуживания и наиболее эффективным вознаграждениям лояльности [42]. Наука о данных и искусственный интеллект предоставляют огромный потенциал для операторов питания, поскольку конкурентоспособным на быстро развивающемся рынке является тот, у которого есть явное преимущество - способность реализовать персонализированное предложение. 


\section{СОЦИАЛЬНО-ЭКОНОМИЧЕСКИЕ ПРОЦЕССЫ: НОВОЕ ВИДЕНИЕ, ВЫЗОВЫ, ТЕНДЕНЦИИ}

В то же время наложение тренда «персонализации» на решения для психического и эмоционального благополучия порождает активный поиск технологий и рецептур продуктов категории «Healh \&Wellness food», который объединяет следующие сегменты:

функциональные и обогащенные продукты, органические продукты,

продукцию, исключающую отдельные ингредиенты (безглютеновая, безлактозная и пр.), продукцию

натуральную продукцию (Naturally Healthy)

продукцию категории BFY (Лучшее для вас).

В 2017 году мировой рынок «Healh \&Wellness food» оценивался в 702 млрд. долл. со среднегодовым ростом 4,1\% и темпами роста в $1,25-1,5$ раза, опережающими темпы роста мирового ВВП [43]. В России по данным Euromonitor international рынок продуктов «Health and Wellness» вырос на $50,3 \%$, увеличиваясь в среднем на 8,5\% в год на протяжении последних 5 лет [44].

При этом в период с 2014 по 2019 гг. рост сегментов функциональные и обогащенные составил 78\%, Intolerance food - 65\%, BFY и Naturally Healthy порядка 40\%, а органических продуктов на $32,8 \%$. На основе набранных темпов, прогнозируется, что к 2024 году объём российского рынка продуктов Healh \&Wellness превысит миллиард рублей, и этот рост вызван за счёт увеличения разнообразия продуктов этих категорий благодаря чему потребители могут удовлетворять специфические пищевые запросы, гибко формируя свой рацион и замещая ими продукты других категорий.

Говоря о перспективах индустрии питания, важно помнить, что питание, как часть жизни общества подвержено тем же процессам и тенденциям, что и социально - экономические явления и события в целом. И в бизнесе, связанном с пищевой продукцией очень многие потребности, могут быть сформированы на основе диктуемых обществом приоритетов и доминант. 


\section{СОЦИАЛЬНО-ЭКОНОМИЧЕСКИЕ ПРОЦЕССЫ: НОВОЕ ВИДЕНИЕ, ВЫЗОВЫ, ТЕНДЕНЦИИ}

Ocобое значение с этой точки зрения приобретает стремительное развитие трендов устойчивого развития и их гармоничное сплетение с приоритетами, которое провозглашают различные общественные движения, начиная от SLOW FOOD и заканчивая экологическими инициативами привели к поиску вариантов использования «некрасивых» овощей, фруктов и прочих продуктов внешний вид которых не позволяет достаточно полно использовать их для приготовления традиционно приготовляемых блюд. На помощь пришли 3D принтеры [45] и меню, созданные на основе их возможностей в первом в мире ресторане 3D-foodprinting- FoodInk. Цель FoodInk - предоставить своим клиентам максимально качественный 3D-опыт; все здесь напечатано в 3D, от столовых приборов до меню и украшений стола.

12 лет назад пионеры из Массачусетского технологического института разработали «кулинарный принтер», который печатал съедобные продукты, но не создавал их. Далее израильский стартап Redefine Meat с помощью 3Dпринтера создает веганские стейки, которые воспроизводят текстуру, вкус и внешний вид говядины. А японским ученым из Университета Осаки, применив технологию 3D-печати, удалось получить искусственную мраморную говядину. Сначала мясные, а в январе 2022 года появились и рыбные 3D продукты. Так, израильский стартап Plantish создал технологию 3D-печати растительного филе лосося из белков бобовых и экстракта водорослей, которое по текстуре и вкусу полностью имитирует оригинал.

Благодаря постоянно расширяющемуся ассортименту 3D-принтеров для продуктов питания, пользователи имеют в своем распоряжении огромное разнообразие уже разработанных сырьевых ингредиентов и самих принтеров, что позволяет значительно расширять возможный ассортимент. Так ChocEdge, из Испании, создает деликатные произведения искусства из шоколада; ChefJet печатает сахарные геометрические формы; a Foodini печатает пиццу, пасту и пирог с заварным кремом [46]. Кулинарные распечатки все чаще и чаще попадают в изысканные блюда - будь то американские закуски под 


\section{СОЦИАЛЬНО-ЭКОНОМИЧЕСКИЕ ПРОЦЕССЫ: НОВОЕ ВИДЕНИЕ, ВЫЗОВЫ, ТЕНДЕНЦИИ}

влиянием французов в Mélisse в Калифорнии или печатная выпечка в La Boscana в Каталонии.

Эксперты уже предсказывают, что печать продуктов питания станет частью нашей кулинарной жизни, как в ресторанах, так и дома. Производители утверждают, что, в отличие от серийно выпускаемых промышленных пищевых продуктов, интеллектуальные фуд-принтеры фактически улучшают наше питание, позволяя нам печатать свежие, полезные для здоровья блюда прямо на наших кухнях - максимальная прозрачность при минимальных затратах времени и усилий.

Также в такие смеси легко добавлять перед печатью необходимые ингредиенты, например, витамины и минералы. В этом случае мы имеем возможность уже говорить об индивидуальном подходе, а если процесс корректировки обогатителей контролируется медициной, то о персонализированном питании. Перспектива иметь возможность добавлять различные питательные вещества к одной и той же пище, адаптируя и приспосабливая ее к вкусу и потребностям отдельных потребителей, будет трансформировать область исследований новых потребностей и вариантов их удовлетворения.

Еще одним преимуществом этой технологии является возможность создания вкусных и безопасных блюд для людей, страдающих дисфагией. Дисфагия - медицинский термин, обозначающий затрудненность глотания и невозможность есть твердую пищу. Так, например для 5 миллионов человек в Германии, страдающих дисфагией, протертая пища в трехмерной форме может оказаться не чем иным, как революционной находкой.

Также использование 3D печати в рамках южноафриканского стартапа [47] компанией Studio H позволило решить проблему «дискриминацией фруктов» путем запуска проекта Salad 2.0. Стартап превращает «уродливые» фрукты в вкусные фруктовые пюре, а затем использует 3D-принтеры, чтобы придать им креативный вид. Помимо того, что яблокам и бананам, которыми 
пренебрегли бы в других условиях, дается возможность быть использованными в пищу (что решает глобальную проблему снижения пищевых отходов), 3D-печать также делает здоровую еду более привлекательной для детей.

Вообще направление активного использование в пищу того, что по каким-то причинам ранее не использовалось, набирает существенные обороты. И здесь вопрос не только в переработке продуктов, имеющих дефекты внешнего вида (помидоры, которые используются для тушения или продукты, которые будут измельчены в процессе приготовления). Вопрос встает о нахождении кулинарного применения продуктам полностью - zerowaste cooking trends. И на этой идеологической базе уже успешно развилось несколько концепций в индустрии питания.

День за днем совладелец ресторана Teaism Мишель Браун (Вашингтон, округ Колумбия) смотрел, как выбрасываются фунты стеблей брокколи, остатки цветочков, украшавших поданную в коробках для бенто еду и думал что можно с этим сделать. Шеф-повар Элисон Своп пересмотрел свои подходы, что привело к появлению в меню ресторана специального раздела «Мусор или Сокровище» - «Trash or Treasure». В блюдах этой категории отдельно выделены элементы, приготовленные из ингредиентов, которые иначе стали бы отходами.

Вдохновением для меню «Trash or Treasure» от Теaism является шефповар Дэн Барбер [48], который в течение трех недель в 2015 году превратил свой нью-йоркский ресторан Blue Hill в пилот по созданию абсолютно новых блюд, посвященный теме пищевых отходов и повторного использования. Проект WastED сотрудничал с поставщиками по всей пищевой цепи, а также с более чем 20 приглашенными поварами, чтобы придумать блюда из продуктов, которые обычно выбрасывают [49]. Шеф-повар Барбер, автор книги «The Third Plate» (Penguin Press, 2014), является инновационным и признанным лидером в области продовольственной и сельскохозяйственной 


\section{СОЦИАЛЬНО-ЭКОНОМИЧЕСКИЕ ПРОЦЕССЫ: НОВОЕ ВИДЕНИЕ, ВЫЗОВЫ, ТЕНДЕНЦИИ}

политики [50]. В своей ресторанной деятельности он придерживается задачи не просто покупать местные ингредиенты; а пытается создать модель системы питания, которая поддерживает весь локальный ландшафт и поощряет к диалогу между шеф-поварами, потребителями и фермерами для обеспечения их взаимного влияния на решения друг друга, с целью максимизации здоровья, экономических результатов и обеспечения истинного натурального вкуса у изготавливаемых блюд.

Следующим этапом развития концепции устойчивости, выраженным в кулинарных трендах, стали аквапоника [51] и использование нетрадиционных сырьевых ресурсов на основе насекомых [52]. Речь не идёт об узкоспецифических этнических проектах - речь о трендах, которые могут стать основой при создании меню даже сетевых международных концепций.

Аквапоника означает объединение аквакультуры (выращивание водных растений и животных) с гидропоникой (выращивание овощей без почвы) в единую замкнутую систему, где кулинарные изыски и устойчивость идут рука об руку. Реализованный Диего Гальего проект позволяет ему предлагать свою фирменную кухню в новом отеле DoubleTree by Hilton в Фуэнхироле. Он доказывает, что растения и рыба прекрасно сочетаются как в тарелке, так и в экономике.

Реальная технология базируется на том, что рыба выделяет отходы, которые содержат ядовитый аммиак, который специальные бактерии превращают в нитраты - ключевой компонент удобрения. Попадая в корни растений (томаты и салатные овощи) этот богатый питательными веществами коктейль в свою очередь, фильтруется через воду, с целью дальнейшей очистки для безопасной откачки назад к рыбе. Это кругооборот приносит пользу обоим сторонам: растения растут быстрее, занимают меньше места и потребляют меньше воды, в то время как рыбе требуется всего семь кубометров воды на килограмм (что гораздо меньше 100 кубометров, необходимых для выращивания рыбы обычными способами). Фактически, 


\section{СОЦИАЛЬНО-ЭКОНОМИЧЕСКИЕ ПРОЦЕССЫ: НОВОЕ ВИДЕНИЕ, ВЫЗОВЫ, ТЕНДЕНЦИИ}

единственная потеря воды происходит в результате испарения и очистки фильтров машин. Ресторан Sollo, расположенный недалеко от Малаги, является пока единственным рестораном замкнутого цикла в мире и представляет собой своего рода революцию в представлениях о «еде будущего».

Еще один пример экологического мышления - это активное смещение акцентов большинства предприятий индустрии питания в сторону использования растительного сырья. Растительные белки, для производства которых требуется значительно меньше ресурсов, заняли второе место среди белковых трендов. Мясо и морепродукты местного производства, которые требуют меньшего количества транспорта и имеют меньший углеродный след, заняли 3-е место, за которым следуют на 4-ом устойчивые морепродукты. Веганство и вегитарианство не мешают при этом создавать блюда, имитирующие привычные продукты животного происхождения. Объем мирового рынка вегетарианских и веганских заменителей мяса на конец 2017 года составил 4,5 млрд.долл. По прогнозам, к 2054 году 1/3 производимых промышленно мясных продуктов заменят растительные альтернативы.

Для концептов предприятий индустрии питания, использующих растительные заменители мяса, наступает эпоха расцвета. Так, с тех пор как международная сеть гамбургерных Umami Burger начала выпускать Impossible Burger в 2017 году, она стала лидером продаж plant-based новинки, на которую теперь приходится треть всех продаж бургеров, продаваемых в США, Японии, Мексике и на Багамских островах. Еще более резко изменились продажи в Финляндии в сети бургеров Bun2Bun, которые выросли на 400\%, когда бренд решил отказаться от всех своих говяжьих гамбургеров в пользу полностью веганского меню, сосредоточенного вокруг Beyond Burger.

Компания Impossible Foods использует белки из корней сои, генномодифицированные дрожжи и воспроизводит структуру и цвет натурального мяса. В мае 2019 года компания привлекла 300 млн долларов инвестиций, 
оценка ее стоимости на рынке выросла до 2 млрд долларов. Ближайший ее конкурент - Beyond Meat - в том же мае привлек на IPO 240 млн долларо [53].

Состав «гамбургера с кровью» растительного происхождения - изолят горохового белка, экспеллерное масло канола, полученное прессованием, рафинированное кокосовое масло, вода, дрожжевой экстракт, мальтодекстрин, натуральные ароматизаторы, гуммиарабик, подсолнечное масло, соль, янтарная кислота, уксусная кислота, генетически немодифицированный пищевой крахмал, целлюлоза из бамбука, метилцеллюлоза, картофельный крахмал, экстракт сока свеклы (для цвета), аскорбиновая кислота (для сохранения цвета), экстракт аннатто (для цвета), цитрусовый фруктовый экстракт (для сохранения качества), овощной глицерин.

World Resources Institute's Better Buying Lab, которая в течение последних двух лет исследовала устойчивые словосочетания, способствующих увеличению продаж растительных элементов меню выделила максимальную успешность таких концепций, как: «без мяса», «веганская» и «вегетарианская» и «обезжиренный».

Успешным кейсом на российском рынке является компания Greenwise, которая работает с 2017 года и делает высококачественную имитацию мяса на основе растительного сырья. Стартап сотрудничает с «ВкусВиллом», «Азбукой вкуса», X5 Retail Group, его продукция продается через все основные маркетплейсы: Wildberries, «Яндекс.Беру», Ozon, 4Fresh. Мощность производства - 20 тонн в месяц, выручка за первый квартал 2020 года составила более 6 млн рублей. Стартап наподобие Good Catch Foods продвигает мясо краба и рыбу, произведенных на растительной основе.

Стратегии продвижения plant-based блюд, направлены на то, чтобы повысить их привлекательность для посетителей - это предложение большего разнообразия блюд, адаптация существующих рецептов для уменьшения содержания мяса, добавление лучших вкусовых и визуально привлекательных 
растительных ингредиентов, внесение изменений в гарниры,

сопровождающие блюда на тарелке. «Ешь овощи!» стало лозунгом посетителей предприятий индустрии питания, разделяющих приоритеты социально - ответственного потребления. Однако помимо растительной альтернативы индустрия питания использует целый комплекс альтернативных источников белка.

Сегодня в мире применяется несколько десятков технологий производства искусственного мяса, которые можно разделить на три группы. Первую составляет уже описанная выше имитация мяса из растительного сырья. Второе направление заключается в выращивании мяса из животных клеток - преимущественно стволовых, но не только. Тут можно отметить компанию Memphis Meats, которая выращивает в биореакторах курятину и утятину из эмбриональной сыворотки птенцов. В 2020 году компания привлекла 161 млн долларов. А в SuperMeat научились делать куриную печенку.

Третье направление - белок одноклеточных. Например, английская Quorn выпускает микопротеины на основе нитевидного грибка Fusarium venenatum, смешанного с яичным белком (с картофельным в варианте для вегетарианцев). В 2019 году компания выпустила на рынок Великобритании веганский колбасный рулет, в 2020 начала производить имитацию стейков. Продукция Quorn продается почти во всех странах Европы [54].

Еще одно направление среди альтернативных белковых источников это насекомые. Gourmet Grubb - новая компания из Кейптауна которая производит богатое белком мороженое, без сахара, с высоким содержанием целого комплекса витаминов и минералов разных вкусов: шоколадное, арахисовое со вкусом чая мате или рождественских специй на основе EntoMilk [55]. EntoMilk тм - это альтернатива молочной основе, полученная из насекомых (личинок мyх black soldier). Этот богатый, сливочный, полный питательных веществ, компонент для мороженого является устойчивым и 
экологически безопасным источником пищи. Название EntoMilk тм происходит от термина «энтомофагия», то есть практики поедания насекомых.

Технологи Bugfoundation (бургерной в Германии) нашли способ сделать насекомых полезными для быстрого питания и основным ингредиентом гамбургера является смесь червей и соевого белка [56]. Первый немецкий бургер из насекомых содержит следующие ингредиенты: $45 \%$ регидратированного белка (60\% буйволиный червь Alphitobius Diaperinus, $40 \%$ концентрат соевого белка), вода, рапсовое масло, лук, яичный белок (сушеный), томатный концентрат (помидоры, соль), соевый соус (вода, соя, пшеница, соль), горчица (вода, семена горчицы, уксус, соль, сахар, специи), картофельный крахмал, специи, соль, лимонный сок, петрушка. Концепция получила очень широкий резонанс и высокие перспективы на распространение по Европе путем создания сети франшизных предприятий.

В целом же современный продовольственный рынок Food Net - это высокотехнологичный рынок производства и потребления продуктов питания, который поделен на метасегменты и для индустрии питания наиболее важными на нем являются: альтернативные источники белка и инновационные продукты питания (в том числе, клеточное мясо/рыба, а также мясные, рыбные и молочные продукты на основе растительного сырья (восстановленные в лабораторных условиях), протеин из насекомых, протеин из метана, протеин из водорослей, а также free from продукты (безглютеновые продукты, продукты без содержания сахара и прочие здоровые продукты питания), а также персонализированное питание (в том числе, сервисы по персонализированному питанию, основанные на анализе ДНК и микробиома кишечника, а также новые технологии функционального питания и персонализированная медицина). Объемы этих сегментов в совокупности составят к 2025 году порядка 17,5 млрд долл.[57]. (табл 2) и это значительно 
изменит сформированную на сегодняшний день конъюнктуру рынка предприятий питания.

Таблица 2

Объем мирового рынка FoodTech в разрезе основных метасегментов

\begin{tabular}{|c|c|c|c|}
\hline Направление & $\begin{array}{r}2018 \text { г, } \\
\text { млн \$ }\end{array}$ & $\begin{array}{c}2025 \text { г, млн } \\
\$\end{array}$ & $\begin{array}{c}\text { Среднегодовой } \\
\text { темп прироста, } \\
\%\end{array}$ \\
\hline $\begin{array}{l}\text { Новые источники белка и } \\
\text { инновационные продукты } \\
\text { питания, в том числе }\end{array}$ & 341 & 5971 & \\
\hline клеточное мясо & - & 200 & - \\
\hline $\begin{array}{l}\text { мясо из растительного сырья } \\
\text { (восстановленное в } \\
\text { лабораторных условиях) }\end{array}$ & 160 & 4000 & 58,4 \\
\hline $\begin{array}{l}\text { рыба из растительного сырья } \\
\text { (восстановленная в } \\
\text { лабораторных условиях) }\end{array}$ & 12 & 330 & 60,5 \\
\hline $\begin{array}{l}\text { альтернативные молочные } \\
\text { продукты из растительного } \\
\text { сырья (восстановленные в } \\
\text { лабораторных условиях) }\end{array}$ & 20 & 350 & 50,5 \\
\hline $\begin{array}{l}\text { яйца из растительного сырья } \\
\text { (восстановленные в } \\
\text { лабораторных условиях) }\end{array}$ & 5 & 75 & 47,2 \\
\hline
\end{tabular}


Продолжение таблицы 2

\begin{tabular}{|l|c|c|c|}
\hline протеин из насекомых & 144 & 1336 & 37,5 \\
\hline $\begin{array}{l}\text { Персонализированное питание } \\
\text { (включая всю экосистему - } \\
\text { сервисы, диагностические }\end{array}$ & 7200 & 11200 & 7,0 \\
$\begin{array}{l}\text { компаниии, функциональные } \\
\text { продукты питания, витамины, } \\
\text { БАД и т.д.) }\end{array}$ & & & \\
\hline
\end{tabular}

Источник: J'son \& Partners Consulting, (в том числе, на основе данных Zion Market Research, MarketsandMarkets, Orbis Research, Allied Market Research, SmiTHers Pira, Marketstudyreport,Axiom Market Research \& Consulting)

Все вышеперечисленные тренды приводят к необходимости появления новых регламентов и НПА, регулирующих создание новых блюд на основе использования подобного сырья. Novel Food - это пища, которая не имеет значительной истории потребления или производится способом, который ранее не использовался пищевых продуктов. Это тип новых продуктов питания, которых раньше не было ни на одном региональном или глобальном потребительском рынке, которые разрабатываются на основе использования биотехнологических / биоинженерных методов. В Европе для определения статуса Novel Food, к которым относят новые пищевые продукты или новые пищевые ингредиенты не имеющих истории «значительного» потребления в Европейском Союзе до 15 мая 1997 года, создаются новые каталоги [58] и новые пищевые технические регламенты. В них оговаривается, что продукты питания и пищевые ингредиенты, подпадающие под действие этого регламента, не должны:

- «...представлять опасность для потребителя,

- вводить в заблуждение потребителя,

- отличаться от пищевых продуктов или пищевых ингредиентов, 


\section{СОЦИАЛЬНО-ЭКОНОМИЧЕСКИЕ ПРОЦЕССЫ: НОВОЕ ВИДЕНИЕ, ВЫЗОВЫ, ТЕНДЕНЦИИ}

которые они предназначены заменить до такой степени, что их нормальное потребление будет неблагоприятно для потребителя с точки зрения питания...»[59].

В Канаде новые продукты регулируются в соответствии с новыми правилами пищевых продуктов, что позволило на сегодняшний день одобрить более 90 новых продуктов для продажи в Канаде. Правила определяют новую еду как:

• «...продукты, которые никогда не использовались в качестве еды,

- пища, полученная в результате процесса, который ранее не использовался в пищу, или,

- пища, которая подверглась генетической модификации и имеет новые черты...»[60].

В России эти процессы также существуют, однако процессы создания и регулирования Novel Food пока не столь активны.

Понятие FoodTech (Food Technologies) — это интеграция цифровых и биотехнологий во всю пищевую цепочку, от фермерских хозяйств и пищевых производств до упаковки, хранения, приготовления и утилизации еды, что предполагает активное использование достижений цифровизации при оказании сервисов в индустрии питания. Так особые возможности раскрываются перед концептами, которые будут активно внедрять голосовую активацию в бизнес - процессы сервиса и производства. Такие, голосовые помощники, как Siri, Google Assistant или Alexa, могут использоваться в ресторанной индустрии для того, чтобы дать по запросу потребителя рекомендацию по выбору предприятия питания, реализовать заказ на доставку или самовывоз через мобильное устройство. А в самом ресторане гости могут взаимодействовать с голосовой активацией, чтобы пообщаться по предлагаемому в меню ассортименту, получить ответы на уточняющие вопросы или рекомендации по сочетаемости или составу блюд, для уточнения 


\section{СОЦИАЛЬНО-ЭКОНОМИЧЕСКИЕ ПРОЦЕССЫ: НОВОЕ ВИДЕНИЕ, ВЫЗОВЫ, ТЕНДЕНЦИИ}

заказа или передачи особых пожеланий, оставляя обслуживающий персонал свободным для выполнения заказов с максимальной скоростью и точностью. При этом важно понимать, что спектр устройств с голосовой активацией растет и сегодня это не только смартфоны, но уже кольца, часы, беспроводные наушники и очки для глаз (например, с поддержкой Alexa).

Применительно к концепциям и меню, разрабатываемых с учетом этих технологий, наиболее вероятным вариантом применения становится интегрированное управление меню. Единая система управления меню - это уникальное решение, позволяющее существенно расширять и гибко вести бизнес. Так, может служить основой для поддержания даже нескольких брендов на достаточно широком географическом рынке, например базовая матрица, которая содержит до 20 и более меню, которые необходимо будет адаптировать к местным заказам, франчайзи, географическим предпочтениям, условиям кейтеринга, доставки на дом, партийной доставке, реализации через киоски самостоятельного заказа и другое. Будущие системы управления меню должны будут корректировать, отслеживать и рассчитывать продажи, а также генерировать отчеты на основе проданных пунктов меню, рабочих мест, мест, персонала, типа заказов, применяемых налогов и т.д. Всё это позволит прогнозировать развитие бизнеса с учетом всей совокупности ограничивающих факторов, находить наиболее оптимальные решения в ценообразовании, стимулировании сбыта, логистических операциях.

В заключение главы следует отметить, что совокупность научных, потребительских, технологических и продуктовых трендов формирует целый спектр новых прогрессивных направлений при создании предприятий питания в ближайшем будущем. В таких предприятиях предлагаемый на рынок ассортимент блюд и напитков может основываться на сезонной доступности ингредиентов, на предложении премиальных здоровых альтернатив «grab-andgo», на большом разнообразии здоровых и устойчивых plant-based блюд, на формировании предложений блюд на основе zero-waste cooking, на основе 
аллерген-дружественных предложений или создающих отдельные меню free from. А разработка этих предложений требует особых технологических и экономических знаний, а также их практической реализации, хотя бы на уровне Food Hall [61], что позволит проверить конкурентоспособность стартапа и жизнеспособность новых концепции и форматов предприятий индустрии питания.

\section{Список литературы}

1. Cifuentes A. Food analysis and foodomics // J. Chromat. - 2009. - Vol. 1216. - P. 7109.

2. Cifuentes A. Comprehensive Foodomics - Elsevier; 1st edition. - 2020. P.2330.

3. Balkir, Pinar \& Kemahlioglu, Kemal \& Yucel, Ufuk. Foodomics: A new approach in food quality and safety. Trends in Food Science \& Technology. - 2020. - Vol.108(3). - DOI 10.1016/j.tifs.2020.11.028.

4. Chaudhary N, Kumar V, Sangwan P, et al. Personalized Nutrition and Omics. Comprehensive Foodomics. - 2021. - P.495-507. —DOI 10.1016/B978-008-100596-5.22880-1.

5. Vecha V.S. Nutrigenomics research: a review / V.S. Vecha, P. Kinth // J. Food Sci. Technol. —2013. - Vol.50 (3). —P. 415-428.

6. Muller M. Nutrigenomics: goals and strategies / M. Muller, S. Kersten // Nat. Rev. Genet. —2003. - Vol.4. - P.315-322.

7. МР 2.3.1.0253-21. 2.3.1. Гигиена. Гигиена питания. Рациональное питание. Нормы физиологических потребностей в энергии и пищевых веществах для различных групп населения Российской Федерации. Методические рекомендации (утв. Главным государственным санитарным врачом РФ 22.07.2021)

8. Концепция «дорожной карты» утверждена экспертной комиссией по рассмотрению дорожной карты рынка FoodNet от 27.11.2020 г [Электронный 
pecypc]. - URL: //https://nti2035.ru/markets/foodnet (дата обращения: 25.01.2022).

9. Probiotics and Prebiotics in Foods:Challenges, Innovations, and Advances by Adriano Gomes da Cruz, C. Senaka Ranadheera, Filomena Nazzaro, Amir Mortazavian. -P 346, - 2021. Academic Press ISBN-13: 978-0-12-8199091, ISBN: 0-12-819909-1.

10. Del Toro-Barbosa M, Hurtado-Romero A, Garcia-Amezquita LE, GarcíaCayuela T. Psychobiotics: Mechanisms of Action, Evaluation Methods and Effectiveness in Applications with Food Products. Nutrients. —2020; - Vol.12(12). -P.3896. — DOI 10.3390/nu12123896.

11. Sarkar A, Lehto SM, Harty S, Dinan TG, Cryan JF, Burnet PWJ. Psychobiotics and the Manipulation of Bacteria-Gut-Brain Signals. Trends Neurosci. -2016 Nov. -Vol.39(11). - P. 763-781. - DOI 10.1016/j.tins.2016.09.002. Epub 2016 Oct 25. PMID: 27793434; PMCID: PMC5102282.

12. Consumer Trends for 2020. - URL: https://www.brandwatch.com/ reports/consumer-trends-for-2020/view/ (accessed: 25.01.2022).

13. WASTED FOOD IS WASTED MONEY. - URL: https://www.goodr.co/aboutus (accessed: 25.01.2022).

14. Teng, Chih-Ching \& Wang, Yu-Mei. Decisional factors driving organic food consumption: Generation of consumer purchase intentions. British Food Journal. — 2015. — Vol. 117. — P. 1066-1081. — DOI 10.1108/BFJ-12-20130361.

15. Nunes, Rubens \& Silva, Vivian \& Kasemodel, Marcia \& Polizer, Yana \& Saes, Maria \& Favaro-Trindade, Carmen. Assessing global changing food patterns: A country-level analysis on the consumption of food products with health and wellness claims. Journal of Cleaner Production. - 2020. — Vol.264. - DOI 10.1016/j.jclepro.2020.121613. 


\section{СОЦИАЛЬНО-ЭКОНОМИЧЕСКИЕ ПРОЦЕССЫ: НОВОЕ ВИДЕНИЕ, ВЫЗОВЫ, ТЕНДЕНЦИИ}

16. New Survey: Gen Y trends that are driving tomorrow's dining economy.

- URL: https://www.ktchnrebel.com/survey-gen-y-trends-restaurants/ (accessed: 25.01.2022).

17. Flagship Fantastic. - URL: https://www.ktchnrebel.com/flagshipfantastic/ (accessed: 25.01.2022).

18. Miškolci, Simona. Consumer preferences and willingness to pay for the health aspects of food. Acta Universitatis Agriculturae et Silviculturae Mendelianae Brunensis. -2011. - Vol.59. - P.167-176. - DOI 10.11118/actaun 201159040167.

19. Pérez-Troncoso, Daniel \& Epstein, David \& García, José. Consumers' Preferences and Willingness to Pay for Personalised Nutrition. Applied Health Economics and Health Policy. — 2011. — Vol.19. — DOI 19. 10.1007/s40258-02100647-3.

20. ONE BITE AT A TIME: CONSUMERS AND THE TRANSITION TO SUSTAINABLE FOOD. - URL: https://www.beuc.eu/publications/one-bite-timeconsumers-and-transition-sustainable-food/ (accessed: 25.01.2022).

21. Глобальные тренды в области питания. - URL: https://nutrition.basf.com/global/en/human-nutrition.html (дата обращения 25.01.2022).

22. MINTEL ANNOUNCES GLOBAL FOOD AND DRINKS TRENDS FOR 2021. — URL: https://www.mintel.com/press-centre/food-and-drink/mintelannounces-global-food-and-drinks-trends-for-2021https (accessed: 25.01.2022).

23. Imagining a new. Culinary possibility. - URL: https://www.creator.rest/ (accessed: 25.01.2022).

24. Henn Na Cafe is Tokyo's Robot Barista. Here's What It Looks Like. URL: https://thespoon.tech/henn-na-cafe-is-tokyos-robot-barista-heres-what-itlooks-like/ (accessed: 28.01.2022).

25. Henn-na Restaurant ROBOT : Famous Restaurant of Huis Ten Bosch. URL: https://www.fun-japan.jp/en/articles/10392 (accessed: 28.01.2022). 
26. Henn Na Cafe is Tokyo's Robot Barista. Here's What It Looks Like. . URL:https://thespoon.tech/henn-na-cafe-is-tokyos-robot-barista-heres-what-itlooks-like/ (accessed: 28.01.2022).

27. This startup is raising $\$ 750$ million to outmaneuver Domino's and Pizza Hut with pizzas made by robots - check it out. - URL: https://www. businessinsider.com/zume-pizza-robot-expansion-2017-6 (accessed: 28.01.2022).

28. At Spyce in Boston's Downtown Crossing robots do the cooking. URL: https://www.youtube.com/watch?v=7goKT_asOo (accessed: 28.01.2022).

29. Робототехника для всех: интервью с основателем стартапа Endurance. - URL: https://www.mirf.ru/science/endurance-robotechnicsinterview/ (дата обращения 25.01.2022).

30. Роботы-официанты принимают заказы. - URL: http://www. robogeek.ru/servisnye-roboty/roboty-ofitsianty-prinimayut-zakazy (дата обращения 30.01.2022).

31. Garden Chef Herb and Microgreen Growing Cabinets. - URL: https://www.carter-hoffmann.com/gardenchef (accessed: 30.01.2022).

32. EQUIPMENT COMPARISONS Should You Buy a Green Growing Cabinet? - URL: https://www.fermag.com/articles/9827-tips-for-growingmicrogreens-at-your-operation/ (accessed: 30.01.2022).

33. Wells WVU Series Universal Ventless Hoods. — URL:. https://wells$\mathrm{mfg} . c o m / p r o d u c t-c a t e g o r y / v e n t l e s s-c o o k i n g-s y s t e m s / v e n t l e s s-h o o d s / \quad$ (accessed: 30.01.2022).

34. Mineral-Filled Polypropylene Hinged Lid Containers. - URL: https://foodie.sysco.com/wpcontent/uploads/2020/05/EarthPlus_MineralFilledHinge Lid.pdf (accessed: 30.01.2022).

35. 9 Food Packaging Trends You Need To Be Aware Of in 2020. — URL: https://bizongo.com/blog/food-packaging-trends/ (accessed: 30.01.2022). 


\section{СОЦИАЛЬНО-ЭКОНОМИЧЕСКИЕ ПРОЦЕССЫ: НОВОЕ ВИДЕНИЕ, ВЫЗОВЫ, ТЕНДЕНЦИИ}

36. Mudie, Samantha \& Essah, Emmanuel \& Grandison, Alistair \& Felgate, R. Electricity use in the commercial kitchen. International Journal of Low-Carbon Technologies. . - 2013. - Vol. 11. — DOI 10.1093/ijlct/ctt068.

37. Subramanian, Karpagam \& Chopra, Shauhrat \& Wharton, Christopher \& Yonge, William \& Allen, Julie \& Stevens, Rozanne \& Fahy, Sam \& Milindi, Paschal. Mapping the Food waste-Energy-Water-Emissions Nexus at Commercial Kitchens: A Systems Approach for a More Sustainable Food Service Sector. Journal of Cleaner Production. 301. 126856. - 2021. - DOI 10.1016/j.jclepro.2021.126856.

38. ENERGY STAR Guide for Cafés, Restaurants, and Institutional Kitchens. URL:https://www.energystar.gov/sites/default/files/asset/document/CR\%20ES\%20 Restaurant\%20Guide\%202015\%20v8_0.pdf (accessed: 30.01.2022).

39. THE STATE OF RESTAURANT SUSTAINABILITY 2018. - URL: https://conserve.restaurant.org/Downloads/PDFs/2018_Sustainability_FINAL_smal 1.aspx (accessed: 30.01.2022).

40. Pixel pasta: will 3D food printers revolutionize the restaurant industry? URL: https://www.ktchnrebel.com/3d-food-printer-restaurant/ (accessed: 30.01.2022).

41. 20 global foodservice trends for 2020. - URL: https://www.ktchnrebel.com/foodservice-trends-2020/ (accessed: 30.01.2022).

42. Restaurant tech evolution. - URL: https://www.restaurant. org/articles/news/restaurant-tech-evolution (accessed: 30.01.2022).

43. Wellness Economy Monitor 2018, Global Wellness institute - URL: https://globalwellnessinstitute.org/wpcontent/uploads/2018/10/Research2018_v5FI NALExecutiveSummary_webREVISED.pdf (accessed: 30.01.2022).

44. Health and Wellness in Russia. - URL: https://www. euromonitor.com/health-and-wellness-in-russia/report (accessed: 30.01.2022).

45. Sandhu, Kamalpreet \& Singh, Sunpreet. Food Printing: 3D Printing in Food Industry. Publisher: Springer. —2021. 


\section{СОЦИАЛЬНО-ЭКОНОМИЧЕСКИЕ ПРОЦЕССЫ:

46. 3D print a pizza with the foodini kitchen appliance. - URL: https://www.designboom.com/technology/3d-print-a-pizza-with-the-foodinikitchen-appliance-12-06-2013/ (accessed: 05.02.2022).

47. Hold your idea in your hand - Morgan 3D Printers. - URL: https://studio-h.co.za/ (accessed: 05.02.2022).

48. Chefs tap zero-waste cooking as sustainability trend for 2019. - URL: https://www.restaurant.org/articles/news/zero-waste-cooking-sustainability-trend2019 (accessed: 05.02.2022).

49. Tackling global issues by targeting food waste. - URL: https://www.latimes.com/food/la-fo-food-waste-20150502-story.html (accessed: 05.02.2022).

50. Why Chef Dan Barber Turned His Restaurant Into a Food Processing Facility. - URL: https://marker.medium.com/why-chef-dan-barber-turned-hisrestaurant-into-a-food-processing-facility-6aaf0d3d0e9a (accessed: 05.02.2022).

51. Aquaponics: symbiotic habitats for food of the future. - URL: https://www.ktchnrebel.com/aquaponic-food-future/ (accessed: 05.02.2022).

52. Bugs, not bunny: how insects are revolutionizing gastronomy. - URL: https://www.ktchnrebel.com/insect-based-protein/ (accessed: 05.02.2022).

53. This report analyzes emerging trends across food, beverage, and household essentials categories using the CB Insights NExTT framework. - URL: https://www.cbinsights.com/research/report/food-beverage-trends-2020/ (accessed: 05.02.2022).

54. К 2035 году мировой объем foodnet может составить порядка 5,9 трлн долларов. - URL: http://biotech2030.ru/k-2035-godu-mirovoj-obemfoodnet-mozhet-sostavit-poryadka-5-9-trln-dollarov/ (дата обращения: 10.02.2022)

55. Dairy Alternatives Made with Entomilk.- URL: https:// gourmetgrubb.com/ 
56. Germany's first insect burger. - URL: https://www.bugfoundation. com/home-en.html (accessed: 10.02.2022).

57. Апалькова, Г.Д. Подходы к формированию рынка пищевых продуктов нового формата / Г.Д. Апалькова, Н.В. Попова, А.Д. Ликсунова // Вестник ЮУрГУ. Серия «Пищевые и биотехнологии». - 2020. - Т. 8, № 4. - С. 5-12. DOI: 10.14529/food200401.

58. Союзный список новых продуктов питания - URL: https://ec.europa.eu/food/safety/novel-food/authorisations/union-list-novelfoods_en (accessed: 10.02.2022).

59. Regulation (EC) No 258/97 of the European Parliament and of the Council of 27 January 1997 concerning novel foods and novel food ingredients consolidated version of 7.8.2009

60. Factsheets and Frequently Asked Questions - Genetically Modified Foods and Other Novel Foods". aem. Health Canada. 27 July 2003.

61. What is a Food Hall? - URL: https://www.webstaurantstore. com/blog/2950/ what-is-a-food-hall.html (accessed: 10.02.2022).

( Л.Н. Рождественская, 2022 